\title{
Human Security In The Sustainable Development Goal 5 (SDGs 5) And Its Implementation In Indonesia
}

\author{
Junita Budi Rachman, Yanyan Mochamad Yani, Sayitri Aditiany \\ Department of International Relations \\ UniversitasPadjadjaran \\ junita@unpad.ac.id
}

\begin{abstract}
This paper is a concern with human security, women matters, and the Sustainable Development Goals numbered 5. The United Nations addressing gender equality and empower all women and girls in SDGs 5 that must be implemented and achieved by all its members in their countries, including Indonesia. Since global attention to security issues focuses more on human beings than on the state, therefore sex and gender are important aspects. Women are one of the human beings, who are as sex and gender very vulnerable to insecurity issues in various areas of life. The areas of life in human security defined by UNDP in 1994 include economy, food, environment, personal, community and politics. Using human security approaches in international relations study, the purpose of this paper is to identify whether these areas of human security are represented in SDGs Goal 5 and to know how they are organized and implemented in Indonesia. It is argued that gender equality for women in accordance with The Sustainable Development Goal 5 and its implementation in Indonesia can be achieved when considering the areas of human security thoroughly.
\end{abstract}

Keywords: Human Security; Goal 5; Agenda SDGs

\section{INTRODUCTION}

Since the end of the Cold War and the increasingly massive globalization era, the focus and locus of security have shifted, from national security to human security. Human security includes freedom from fear and freedom from want for all individuals around the world, in the fields of economy, food, health, environment, personal, community and politics. Countries in the world have agreed through the UN or UNDP to work together to make the world better, safe, prosperous and livable place to live by using human security approaches through a series of sustainable programs. The agenda of UN Sustainable Development Goals (SDGs), in which the number 5 goal (Goal 5) is equality and empowerment of woman is being implemented by Indonesia to achieve it in accordance with the required targets. Indonesia has long been committed to reducing gender disparities between women and men by making policies and implementing national gender empowerment programs. The question is whether implementation of Goal 5 in Indonesia is convergence with the goal of human security?

\section{HUMAN SECURITY AND ITS RELATIONSHIP WITH SUSTAINABLE DEVELOPMENT GOALS (SDGS)}

\section{A. Concept of Human Security}

There are several definitions of human security. First and most-commonly cited usage came in the United Nations Development Programs (UNDP) 1994 Human Development Report. Defining human security as "safety from such chronic threats as hunger, disease and repression" and "protection from sudden and hurtful disruptions in the patterns of daily life," the UNDP broadened the conceptualization of security, from statecentric approach to individual-centric approach. It encompasses seven key components: economic security, food security, health security, environmental security, personal security, community security, and political security. ${ }^{1}$ In this report, a whole chapter was devoted to the 'New Dimensions of Human Security', as well as stating that human security was universal; its components interdependent; based upon preventative, and intrinsically people-centered. ${ }^{2}$ To the Human Development Report, 2001, entitled Human SecurityNow - reaffirmed the goal of human security: "to protect the vital core of all human lives in ways that enhance human

\footnotetext{
${ }^{1}$ United Nations Development Programs (1994): Human Development Report. 1994: 22-23,

${ }^{2}$ Ibid
} 
freedoms and human fulfillment... protecting fundamental freedoms... protecting people from critical (severe) and pervasive (widespread) threats and situations". ${ }^{3}$ MahbubulHaqin 1995 said that human security is not a concern with weapons. It is a concern with human dignity. ${ }^{4}$ Kofi Annan in 2001, argued that human security can no longer be understood in purely military terms. Rather, it must encompass economic development, social justice, environmental protection, democratization, disarmament, and respect for human rights and the rule of law. Moreover, these pillars are interrelated; progress in one area generates progress in another. ${ }^{5}$

In the academic world, an openhandedness of the concept is necessary for a dynamic conceptualization of human security, stating: "What people consider being "vital" - what they consider being "of the essence of life" and "crucially important" - varies across individuals and societies." Hence, human security that focused specifically on the individual could easily adapt to various cultural specificity.

AmartyaSen (1999) argued that Development can be seen as a process of expanding the freedoms that people enjoy. According to him, there are five distinct types of freedom: political, economic facilities, social opportunities, transparency guarantees, and protective security freedom.This approach contrasts with conventional definitions of development with the growth of GNP, rise in personal incomes, or with industrialization, technological advance, or social modernization. These are all important but are means and not ends. Freedoms depend also on other determinants e.g. social and economic arrangements (e.g. education and health facilities), political and civil rights. ${ }^{6}$

Strategies for improving human security globally are through sustainable development programs provided by the UN. Among them are the Millennium Development Goals (MDGs) and Sustainable Development Goals (SDGs).

\section{B. Relationship with Women (Women Human Security)}

Susan McKay (2004) presents a feminist framework of human security. A key feminist question about human security is whose security is emphasized, how do ordinary women define

\footnotetext{
${ }^{3}$ Human Security in Theory And Practice, An Overview Of The Human Security Concept And TheUnited Nations Trust Fund For Human Security. Human Security Unit. United Nations: New York. Page 5

${ }^{4}$ AmitavAcharya. Chapter 28.Human Secuirty. Page 493

5 ibid

${ }^{6}$ Amarta K. Sen. 1999. Development as Freedom.Anchor Books: New York. Pp 1-4
}

human security as compared with prevailing meanings, and what forces in a nation or community create, reinforce, and maintain gendered conditions of human insecurity. ${ }^{7}$

McKayargues that to improve human security, insecurity of girls and women must be an international priority to be solved.As she said, that girls and women experience human insecurity differently from men and are subject to gender hierarchies and power inequities that exacerbate their insecurity. Due to their inferior status, girls and women are less able to articulate and act upon their security needs, as compared with boys and men. ${ }^{8}$

As noted by Holzner and Truong that "all forms of human (in)security are gendered, because social structures, practices, and symbols in societies are gendered. ${ }^{9}$ Furthermore, Ulf Kristofferson said, "Whether it is economic security, food security, health security, personal or political security, women and young girls are affected in a very specific way due to their physical, emotional and material differences and due to the important social, economic, and political inequalities existing between women and men." 10

Beth Woroniuk drew attention to key gendered dimensions that have been missing within human security discussions, notably: violence against women, gender inequality in control over resources, gender inequality in power and decision making, women's human rights, and women as actors, not victims. ${ }^{11}$

\section{Relationship with Development}

Between human security and human development, there are inextricably linked since progress in one enhances the chances of progress in another while failure in one increases the risk of failure of another. As Frances Stewart in "Development and Security" argues that security and development are deeply interconnected: (1) Human security forms an important part of people's well-being, and is therefore an objective of development. (2) Lack of human security has adverse consequences on economic growth, and therefore development. (3) Imbalanced development that involves horizontal inequalities is

${ }^{7}$ Susan McKay. IPSHU English Research Report Series No.19 Conflict and Human Security: A Search for New Approaches of Peacebuilding(2004)

${ }^{8}$ ibid

${ }^{9}$ ibid

${ }^{10}$ ibid

${ }^{11}$ Ibid 
an important source of conflict.12Furthermore, it could also be said that the practice of human development and human security share three fundamental elements:(1) human security and human development are both people-centered; (2) both perspectives are multidimensional as. (3) Both schools of thought consider poverty and inequality as the root causes of individual vulnerability. ${ }^{13}$

\section{Relationship with SDGs Goal 5}

The Sustainable Development Goals (SDGs), are a universal call to action to end poverty, protect the planet and ensure that all people enjoy peace and prosperity. There are 17 Goals to be implemented by the member countries of UN. One of the goals is Goal 5.14

Under the traditional security model, human security focuses on the serious neglect of gender concerns and the majority of threats women face has been overlooked. However, as of recent conflicts, it is believed that the majority of war casualties are civilians, and most of the adult civilians are women as the victim of war. In postwar, process of the development has threatened women security by unequal access to resources, services and opportunities. Such cruel customary practices are still in existence because of women's vulnerability in economic independence and security. Human security in relationship to gender tries to overthrow such traditional practices that are incompatible with the rights of women. Also human security seeks to empower women, through education, participation, and access, as gender equality is seen as a necessary precondition for peace, security and a prosperous society.

TABLE I. HUMAN SECURITY AND SDGS GOAL 5

\begin{tabular}{|l|l|l|}
\hline \multicolumn{2}{|c|}{ Human Security } & $\begin{array}{l}\text { SDGs Goal 5 } \\
\text { Target }\end{array}$ \\
\hline $\begin{array}{l}\text { Component } \\
\text { security }\end{array}$ & $\begin{array}{l}\text { insured } \\
\text { basic income } \\
\text { and } \\
\text { employment, } \\
\text { and access } \\
\text { to such } \\
\text { social safety } \\
\text { reforms to give } \\
\text { women equal } \\
\text { rights to } \\
\text { economic } \\
\text { resources, as } \\
\text { nell as access } \\
\text { to ownership } \\
\text { and control } \\
\text { over land and }\end{array}$ \\
\hline
\end{tabular}

${ }^{12}$ Frances, Stewart, (2004). "Development and Security", Centre for Research on Inequality, Human Security, and Ethnicity (CRISE), Working Paper 3, London: University of Oxford.

${ }^{13}$ Alkire, Sabina. 2002. A conceptual framework for human security. working paper no. 2

${ }^{14}$ https://sustainabledevelopment.un.org/

\begin{tabular}{|c|c|c|}
\hline & & $\begin{array}{l}\text { other forms of } \\
\text { property, } \\
\text { financial } \\
\text { services, } \\
\text { inheritance } \\
\text { and natural } \\
\text { resources, in } \\
\text { accordance } \\
\text { with national } \\
\text { laws } \\
5.8 \text { Enhance } \\
\text { the use of } \\
\text { enabling } \\
\text { technology, in } \\
\text { particular } \\
\text { information } \\
\text { and } \\
\text { communication } \\
\text { s technology, to } \\
\text { promote the } \\
\text { empowerment } \\
\text { of women }\end{array}$ \\
\hline Food security & $\begin{array}{l}\text { access to } \\
\text { basic } \\
\text { nutrition } \\
\text { and food } \\
\text { supply }\end{array}$ & 5.7 \\
\hline $\begin{array}{l}\text { Health } \\
\text { security }\end{array}$ & $\begin{array}{l}\text { Access to } \\
\text { preventative } \\
\text { / curative } \\
\text { medicines } \\
\text { and services, } \\
\text { nutrition, } \\
\text { clean water, } \\
\text { clothing. } \\
\text { Having safe } \\
\text { and } \\
\text { affordable } \\
\text { family } \\
\text { planning and } \\
\text { basic } \\
\text { support } \\
\text { during } \\
\text { pregnancy } \\
\text { and delivery. }\end{array}$ & $\begin{array}{l}53 . \text { Eliminate } \\
\text { all harmful } \\
\text { practices, such } \\
\text { as child, early } \\
\text { and forced } \\
\text { marriage and } \\
\text { female genital } \\
\text { mutilation } \\
5.6 \text { Ensure } \\
\text { universal } \\
\text { access to } \\
\text { sexual and } \\
\text { reproductive } \\
\text { health and } \\
\text { reproductive } \\
\text { rights as } \\
\text { agreed in } \\
\text { accordance } \\
\text { with the } \\
\text { Programed of } \\
\text { Action of the } \\
\text { International } \\
\text { Conference on } \\
\text { Population and } \\
\text { Development } \\
\text { and the Beijing } \\
\text { Platform for } \\
\text { Action and the } \\
\text { outcome }\end{array}$ \\
\hline
\end{tabular}




\begin{tabular}{|c|c|c|}
\hline & & $\begin{array}{l}\text { documents of } \\
\text { their review } \\
\text { conferences }\end{array}$ \\
\hline $\begin{array}{l}\text { Environment } \\
\text { al security }\end{array}$ & $\begin{array}{l}\text { Policies and } \\
\text { practice to } \\
\text { ensure } \\
\text { sustainabilit } \\
\text { y and } \\
\text { protection of } \\
\text { land, air, } \\
\text { water, etc. } \\
\text { and } \\
\text { prevention } \\
\text { of natural } \\
\text { hazards. }\end{array}$ & 5.7 \\
\hline $\begin{array}{l}\text { Personal } \\
\text { security }\end{array}$ & $\begin{array}{l}\text { Safety } \\
\text { against } \\
\text { threats } \\
\text { violence, } \\
\text { crime, war } \\
\text { and abuse }\end{array}$ & $\begin{array}{l}\text { 5.2. Eliminate } \\
\text { all forms of } \\
\text { violence } \\
\text { against all } \\
\text { women and } \\
\text { girls in the } \\
\text { public and } \\
\text { private } \\
\text { spheres, } \\
\text { including } \\
\text { trafficking and } \\
\text { sexual and } \\
\text { other types of } \\
\text { exploitation }\end{array}$ \\
\hline $\begin{array}{l}\text { Community } \\
\text { security }\end{array}$ & $\begin{array}{l}\text { Protection of } \\
\text { community } \\
\text { groups } \\
\text { including } \\
\text { family and } \\
\text { ethnic } \\
\text { groups }\end{array}$ & $\begin{array}{l}\text { 5.4. Recognize } \\
\text { and value } \\
\text { unpaid care } \\
\text { and domestic } \\
\text { work through } \\
\text { the provision } \\
\text { of public } \\
\text { services, } \\
\text { infrastructure } \\
\text { and social } \\
\text { protection } \\
\text { policies and the } \\
\text { promotion of } \\
\text { shared } \\
\text { responsibility } \\
\text { within the } \\
\text { household and } \\
\text { the family as } \\
\text { nationally } \\
\text { appropriate } \\
5.9 \text {. Adopt and } \\
\text { strengthen } \\
\text { sound policies } \\
\text { and enforceable } \\
\text { legislation for } \\
\text { the promotion }\end{array}$ \\
\hline
\end{tabular}

\begin{tabular}{|c|c|c|}
\hline & & $\begin{array}{l}\text { of gender } \\
\text { equality and } \\
\text { the } \\
\text { empowerment } \\
\text { of all women } \\
\text { and girls at all } \\
\text { levels }\end{array}$ \\
\hline $\begin{array}{l}\text { Political } \\
\text { security }\end{array}$ & $\begin{array}{l}\text { Provision of } \\
\text { human } \\
\text { rights, right } \\
\text { to vote, and } \\
\text { express } \\
\text { political } \\
\text { view. }\end{array}$ & $\begin{array}{l}\text { 5.1. End all } \\
\text { forms of } \\
\text { discrimination } \\
\text { against all } \\
\text { women and } \\
\text { girls } \\
\text { everywhere } \\
5.5 \text { Ensure } \\
\text { women's full } \\
\text { and effective } \\
\text { participation } \\
\text { and equal } \\
\text { opportunities } \\
\text { for leadership } \\
\text { at all levels of } \\
\text { decision- } \\
\text { making in } \\
\text { political, } \\
\text { economic and } \\
\text { public life }\end{array}$ \\
\hline
\end{tabular}

\section{IMPLEMENTATION OF HUMAN SECURITY AND SDGS GOAL 5 IN INDONESIA}

Indonesia, like other developing countries, has embraced SDGs as the basis for formulating its development and gender empowerment strategies. In implementing SDGs Goal 5, Indonesia at the same time should also consider its access to human security, especially for women and girls.

\section{E. Economic Security and SDGs Goal 5.7. Goal 5.8}

Girls and women in Indonesia, especially in the rural areas are still in a condition of poverty. Economic security insured basic income and employment, and access to such social safety net to everyone, including to women. The government of Indonesia undertakes reforms to give women equal rights to economic resources, as well as access to ownership and control over land and other forms of property, financial services, inheritance and natural resources, in accordance with national laws (G.5.7.). There is no limitation in Indonesia for women or girls to enhance the use of enabling technology, in 
particular information and communications technology, to empower them self (G 5.8.)

\section{F. Food Security and SDGs Goal 5.7, Goal 5.8}

Food security is about accessibility, adequacy and availability for everyone, including for women to have enough healthy food. Women play a critical role in dietary diversity and children's health. The government of Indonesia has to secure food security not only the stability of its availability but also the stability of domestic politics. Indonesia women are given access to ownership and control over food and other instruments to make their own food and to grow their own food to feed the family and their selves (G 5.7 and G 5.8) Department of Agriculture efforts in supporting micro-farming of rural communities to include women in substantive roles.

\section{G. Health Security and SDGs Goal 5.3, 5.6}

Health security concerns for women in Indonesia, especially in rural area, have been inaccessibility and affordability of medication, lack of maternal health care, poor hospital facilities and lack of medical and health professionals. (G. 5.6) Government to prioritize maternal health care facilities and make sure those women in rural areas are able to access health facilities without any undue burden. Eliminate early and forced marriage for girls under 17 years old ( $G$ 5.3).

Indonesian government policies on health for Women and Girls include General Policy on Reproductive Health, Empowerment Strategies for Maternal and Child Health, Family Planning, and Prevention and Control of HIV / AIDS.

\section{Environmental Security and SDGs Goal 5.7}

The government of Indonesia have to conduct policies and practice to ensure sustainability and protection of land, air, water, etc. and prevention of natural hazards (G.5.7) to serve girls and women in maintaining their daily lives.The Government of Indonesia in 2017 says it will focus on equity efforts, reduce the gap through the policy of redistribution of assets and people's access to land, especially those relating to customary lands and strengthening people's access to capital. This policy is endeavored to conform to the interests of women and other vulnerable groups.

\section{E.Personal Security and SDGs Goal 5.2.}

Personal security for girls and women encompassed living without fear and carrying out their productive and personal roles without fear of violence. Eliminate all forms of violence against all women and girls in the public and private spheres, including trafficking and sexual and other types of exploitation. Training on gender equality must be compulsory for all local, district and divisional level planning committee members to make certain of accountability to women's human rights conventions and UNSCRs. ${ }^{15}$ Various efforts have been made by the Indonesian government in following up these illegal practices.

In 2007, UU No 21 was issued by the Indonesian government which regulates the eradication of the crime of trafficking in persons.KementerianPemberdayaanPerempuand anPerlindunganAnak (The Ministry of Women's Empowerment and Child Protection) in 2016 stating its commitment on the eradication of trafficking of women and children, the handling of cases of sexual violence against women and children and gender equality programs and women's empowerment. (G 5.2)

\section{F. Political Security and SDGs Goal 5.1, Goal 5.5}

Cultural and social barriers were identified as preventing women from participating in decision-making. Provision of human rights, right to vote, and express political view for girls and women to end all forms of discrimination against all women and girls everywhere (G.5.1) and to ensure women's full and effective participation and equal opportunities for leadership at all levels of decision-making in political, economic and public life. (G.5.5) Therefore the Government of Indonesia and political parties have been adopted quotas and temporary special measures to actively promote democracy in all peace and security decision making, including at least 30 percent representation of women in Parliament, provincial council and district committees, political party leadership, local government, statutory bodies and committees, and through reform of campaign financing frameworks and policies. The Government of Indonesia guarantees women in politics contained in Undang-undangRI No. 31 2002, UndangUndangRI No. 22008 Undang-UndangRI Nomor 2 Tahun 2011 on Political Parties.

\footnotetext{
${ }^{15}$ Equality, Development and Peace: Women's Human Security First. Femlinkpacific policu for peace report.Fiji Island. 2009-2014. www.peaceportal.org
} 


\section{CONCLUSION}

Human security is key to sustainable development and to ensure sustainable human security girls and women must be included. Gender equality for women in accordance with The Sustainable Development Goal 5 and its implementation in Indonesia can be achieved when considering the areas of human security thoroughly

\section{REFERENCES}

[1] Acharya, Amitav. Chapter 28. Human Security. Page 493

[2] Buzan, Barry. People, States, and Fear: An Agenda for International Security Studies in the Post-Cold War Era, $2^{\text {nd }}$ edition. (HemelHempstead: Harvester Wheatsheaf, 1991).

[3] Equality, Development, and Peace: Women's Human Security First. Femlinkpacific police for peace report.Fiji Island. 2009-2014
[4] Frerks, Georg. 2007. Human Security and International Insecurity (edited) by Georg Frerks and Berma Klein Goldewijk. Wageningen Academic Publishers: the Netherlands

[5] McKay, Susan. IPSHU English Research Report Series No.19 Conflict and Human Security: A Search for New Approaches of Peacebuilding(2004)

[6] o

[7] Sabina, Alkire, 2002. A conceptual framework for human security. working paper no. 2

[8] Sen,Amartya.1999. Development as freedom New York: Alfred A. Knorf

[9] Stewart, Frances (2004). "Development and Security", Centre for Research on Inequality, Human Security, and Ethnicity (CRISE), Working Paper '3, London: University of Oxford.

[10] Tadjbakhsh, Shahrbanou andAnuradha $M$. Chenoy. 2007. Human Security, Concept and Implications. Routledge: London

[11] United Nations Development Programme, Human Development Report, 1994 (New York: OxfordUniversity Press, 1994), p. 22. 